\title{
Paulus se 'godsdienspatroon' en die bepaling van verwysing
}

\author{
E Engelbrecht
}

\begin{abstract}
Paul's 'pattern of religion' and the determination of reference

The interpretation of meaning in a Pauline text starts in the micro-context and proceeds via the macro-structure of the letter to Paul's pattern of religion. This implies a synchronic approach. It is argued that a pattern of religion thus constructed functions as a method of control in establishing an interpretation of meaning. Pattern of religion consists of that which is basic to Pauline thinking and the first phase surface motives which are generated by this basic pattern of belief.

The study concludes that the interpretation of meaning in Paul should take note of the uniqueness of Paul's thinking. The method developed is pointed by an interpretation of the meaning of eleos in Romans 15:9.
\end{abstract}

\section{OMSKRYWING VAN DIE DOELSTELLING EN METODE}

Die literêre bedrywigheid in die vroeg-Christelike kerk is opvallend. Dit is nie die hoeveelheid wat geskryf is wat opvallend is nie, maar eerder die relatief baie en wyduiteenlopende genres. Die opvallendste van hierdie literêre bedrywigheid is die besondere selfstandige skeppingskrag van die skrywers. Daar is nie sonder meer 'afgeskryf' of oorgeskryf nie. Ook waar van tradisiestof gebruik gemaak word, is 'n eie perspektief dikwels duidelik. Die teologie in die vroeë kerk was dus nie soseer ' $n$ versameling van tradisies nie, maar veral die interpretasie van die tradisies in eie omstandigheid. Hierdie eie interpretasie is byna konsekwent so opvallend dat daar, sonder die vrees van veel teenspraak, hier van 'n eie teologie gepraat kan word.

Die vooronderstelling van hierdie studie is dat Paulus nie net ' $n$ eie teologie geskep het nie, maar hierdie teologie geskep het vanuit 'n eie godsdienspatroon. Daar word dus veronderstel dat 'n grondstruktuur die denke van Paulus dra. Al antwoord hy dan op verskillende vrae in die gemeentes of al grens hy hom af teen wanopvattings of heidense geloof, bly die grondstruktuur van sy teologie dieselfde.

Die vraag na hierdie grondstruktuur het veral die afgelope dekade na 
vore getree. Sanders (1977) het aangetoon dat sekere elemente, maar veral hulle onderlinge verhouding as grondliggende pattern of religion, Paulus se teologie dra. Patte (1983) sluit by die semantiese teorie van Greimas aan en praat van ' $n$ 'sisteem van oortuigings as semantiese universum'. Hierdie grondstruktuur is die 'milieu' waarin die gelowiges leef. Boers (1984) praat van 'n micro-universe as die diepste vlak waarop ' $n$ teks berus. Omdat elkeen van bogenoemde skrywers 'grondstruktuur' anders sien, funksioneer dit anders in hulle teorie oor verwysing. Om hierdie rede sal in hierdie studie noukeurig beskryf word wat onder godsdienspatroon verstaan word.

Die vraag wat in hierdie studie beantwoord word, is of die vasstelling van Paulus se godsdienspatroon 'n wettige rol kan speel in die bepaling van verwysing. Die vraag hang ten nouste saam met wat onder 'grondliggend' verstaan word. In generatiewe teorieë word daar meer vlakke van grondliggendheid gekonstrueer. Boers (1984) beweeg vanaf die oppervlakte waar konkrete uitsprake oor 'n saak voorkom, dieper na temas en daarvandaan na waardes en daarvandaan na die mikrowêreld (micro-universe). Hierdie mikrowêreld is bar en sê niks oor die Paulusteks nie. Dit is eers as aan hierdie barre fundamentele opposisies in Paulus se denke gestalte gegee word deur konkrete uitsprake (figures) op die oppervlakte, dat die teks betekenis kry (Boers 1984: 133, 138). In hierdie generatiewe teorie van Boers kan die mikrowêreld (die fundamentele opposisies in Paulus se denke wat hy met die hele mensheid deel) op sigself, geen rol speel by die interpretasie van 'n teks se betekenis nie. Die interpretasie van 'n teks se betekenis kan alleen konkreet word as die mikrowêreld èn sy besondere vulling deur die uitsprake op die oppervlakte in ag geneem word.

In hierdie studie word daar nie van so 'n barre mikrowêreld uitgegaan nie. Die godsdienspatroon word nie so diep in wat grondliggend is, vooronderstel dat dit nie ' $n$ rol op sigself in die vasstelling van verwysing kan speel nie. Die vooronderstelling wat hier vir interpretasie ontwerp word, ken 'n relatiewe plek toe aan die rol wat die godsdienspatroon speel. Saam met Boers word dit beklemtoon dat 'n teks betekenis kry vanuit die uitsprake op die oppervlakte.

\subsection{Konstruksie}

Geloof, as godsdienstige kategorie, is die oortuiging van iemand dat 'n Absolute bestaan.* Die 'gelowige' gee inhoud aan hierdie oortuiging in sy teologiese denkarbeid. Hy gee ook inhoud daaraan in sy praktiese

* Prof HG van der Westhuizen, Departement Godsdiens- en Sendingwetenskap, Hervormde Teologiese Opleiding, Klipdrif, het die godsdienswetenskaplike kwessies gekontroleer. Skrywer aanvaar egter verantwoordelikheid. 
vroomheid en rites wat die uitlewing van sy oortuiging en teologiese arbeid is. Die godsdienspatroon van 'n gelowige is 'n konstruksie wat op grond van die gelowige se geloof, praktiese uitlewing en sy teologie gemaak word. Hierdie konstruksie toon die elemente wat grondliggend is vir geloof, teologie en uitlewing. Dit is hierdie grondliggende elemente wat in hulle samehang nie alleen geloof, teologie en uitlewing bepaal nie, maar ook tot ' $n$ sinvolle eenheid saambind. Dit sal daarom juis in die vergelyking van godsdienste se godsdienspatrone wees dat ooreenkoms of verskil die duidelikste na vore kom. Die godsdienspatroon word voorlopig beskryf as die paradigma waarvolgens geloof ontvou in godsdiensuitlewing en teologie.

Ook wanneer godsdienspatroon 'n relatiewe rol speel in interpretasie, word interpretasie hier van konstruksie afhanklik gemaak. Ook in sy relatiewe rol staan godsdienspatroon teenoor die teks. Hiermee is die moontlikheid geopen dat die godsdienspatroon die teks kan verbuig. Om hierdie gevaar te vermy, word ' $n$ metode ontwerp waar in konsentriese sirkels uitbeweeg word vanaf die naaste omgewing van 'n gedeelte oor die dieptestruktuur (grondtema) van 'n besondere brief na die godsdienspatroon van Paulus. Hierdie fases in die interpretasie dien dan wedersyds as kontrole. Indien hierdie fases nie konsentries pas nie, sal dit ' $n$ aanduiding wees dat êrens òf verkeerd geïnterpreteer òf verkeerd gekonstrueer is. Natuurlik is die konstruksie van godsdienspatroon by Paulus afhanklik van die vooronderstelling dat Paulus konsekwent dink. Al sou Paulus nie noodwendig sistematies dink in die sin dat al sy teologiese motiewe altyd ineenskakel en wel só dat 'n hoofmotief al die ander motiewe altyd bepaal nie, dink hy tog konsekwent. Hy dink konsekwent in dié sin dat hy organies dink. Hiermee word bedoel dat alhoewel teologiese motiewe mekaar nie altyd relatief bepaal nie, hulle tog 'n samehang het deurdat hulle gedra word deur'n grondstruktuur wat relatief samehangend is. In 'n grondstruktuur wat relatief samehangend is, is ' $n$ dominante motief en dit is hierdie dominant wat die patroon vorm en bepaal.

Toe daar gestel is dat interpretasie in konsentriese sirkels vanaf die engere gedeelte uitbeweeg, het hierdie proses alreeds 'n sinkroniese metode geïmpliseer. Saam met Güttgemanns (1971: 79) word dus aanvaar dat die sinkroniese linguistiek 'n metodiese voorrang bo 'n diakroniese het. Negatief omskryf, beteken sinkronies dat Paulus se denke nie verstaan word asof dit in die verlenging van een of ander denkrigting lê nie. Daar word dus nie van meet af aan gesoek waarby Paulus aansluit en dan vanuit hierdie aansluiting ' $n$ interpretasie gegee aan die betekenis van die Paulusteks nie. Hiermee word nie alle gods- 
diensvergelykende metodes om interpretasie te help, afgewys nie.

Boers (1984: 132) wys op die ironie daarvan dat die godsdienshistoriese skool se eintlike belangstelling nie die geskiedenis was nie. Hulle ondersoek na godsdienstige uitdrukking was eerder sinkronies as diakronies. Hulle het dus meer aandag aan die feit gegee dat uitdrukkings parallel is as dat daar ' $n$ moontlike historiese ontwikkeling van een uitdrukking na' $n$ ander een was.

Selfs 'n sinkroniese godsdiensvergelyking van parallelle is nie sonder sy probleme nie. Dikwels staan die navorser voor die probleem dat hy die onbekende betekenis van 'n Paulusteks moet interpreteer vanuit 'n net so onbekende betekenis van 'n skynbare parallel.

'n Verdere probleem van 'n sinkronies-godsdienshistoriese verklaring met behulp van parallelle, is dat in godsdienste parallelle dikwels net oppervlakkig is. ' $n$ Sinvolle vergelyking kan alleen gedoen word as die parallelle spruit uit godsdienspatrone wat sterk ooreenkoms vertoon. Sanders (1977: 13, $20 \mathrm{vv}$ ) noem hierdie vergelyking van oppervlakkige parallelle die vergelyking van gedisorganiseerde parallelle. Dit is nie baie moeilik om in te sien dat die verklaring van die betekenis van 'n teks vanuit 'n gedisorganiseerde parallel die teks se betekenis heeltemal sal misvat nie. Sanders (1977: 13) se aandrang op die belang van funksie-in-patroonkonteks by die omskrywing van godsdiensmotiewe sal nie strafloos geïgnoreer word nie. Dit is só bloot omdat 'n vergelyking van elemente wat funksie en konteks buite rekening laat, ' $n$ valse vergelyking is omdat elemente wat vir vergelyking wesenlik is, nie in berekening gebring word nie.

Die belangrikste beswaar teen 'n metode wat bloot diakronies toegang soek tot die Paulusteks, is dat dit nie sinkronies is nie. Die probleem van 'n diakroniese ondersoek is dat dit veronderstel dat die Pauliniese gedagtes stroom-af in die vloei van een of ander godsdiens lê. Die grootste probleem hier is dat die rekonstruksie van hierdie vloeitrajek dikwels hoog hipoteties is (Sanders 1977: $20 \mathrm{v}$ ). Die beswaar teen 'n sinkroniese metode wat veral godsdiensvergelykend werk, is dat motiewe se verband in hulle eie godsdienspatroon dikwels geïgnoreer word, dit wil sê dat hulle funksie in konteks geignoreer word. Die belang van motiewe-in-konteks word ook deur Patte (1983: 25) onderstreep as hy sê dat 'die ware en karakteristieke kenmerk van 'n geloof die patroon is wat gevorm word deur die interverhouding van oortuigings wat saambondel.' 


\section{GODSDIENSPATROON}

Die metode wat hier ontwerp word om Paulus se briewe te interpreteer, hou vas aan die motodiese prioriteit van die sinkroniese metode. Die resiproke verhouding van woorde en frases in die engere verband is bepalend vir die interpretasie van die betekenis van ' $n$ teks. Die tweede fase van interpretasie is wanneer die makrostruktuur van 'n brief in berekening gebring word (vgl Boers 1982: 1). Die derde fase van interpretasie is teen die agtergrond van Paulus se godsdienspatroon. Teen dié agtergrond sal die engere gedeelte reliëf kry en sal dus ook gekontroleer kan word of die interpretasie in die eerste twee fases geslaagd was.

Maar wat word hier onder godsdienspatroon verstaan? Sanders (1977: $16 \mathrm{v}$ ) verstaan onder 'n pattern of religion nie die totaliteit van 'n historiese godsdiens nie, maar dat 'n godsdiens 'n homogene entiteit is. Die godsdienspatroon omvat dus nie elke teologiese uitspraak of godsdienstige opvatting binne 'n godsdiens nie. Patroon wys vir Sanders na die verloop van 'n godsdiens vanaf sy logiese beginpunt tot by sy logiese eindpunt. Positief gestel, beteken dit hoe die aanhangers van 'n godsdiens die funksionering van dié godsdiens verstaan. Op sy tipiese Texaswyse stel hy dat dit beteken 'how getting in and staying in is understood'. Daarom het die godsdienspatroon veral te doen met 'soteriologie'. Sanders se godsdienspatroon beweeg op die vlak van motiefelemente in Paulus se teologie. Hy selekteer die elemente veral aan die hand van die soteriologie en sy patroon dien veral ' $n$ godsdienshistoriese vergelyking. Hierdie patroon funksioneer by Sanders nie primêr as interpretasiehulp om die betekenis van tekste vas te stel nie. Die omskrywing van godsdienspatroon deur Sanders as die manier waarop die aanhangers van 'n godsdiens die funksionering daarvan verstaan, is ' $n$ belangrike element in die omskrywing van godsdienspatroon. 'Aanhangers' is ' $n$ sleutelelement in enige godsdiens. Die funksionering van ' $n$ godsdiens impliseer dat ook die aanhangers funksioneer. Hulle word saamgeneem in 'n belydenis, die rites en in die uitlewing van hulle oortuiging.

Hierdie sleutelrol van 'aanhangers' in die grondstruktuur van 'n godsdiens word ook deur Patte (1983: $21 \mathrm{v}$ ) beklemtoon wanneer hy die grondstruktuur beskryf as ' $n$ 'oortuigingspatroon'. Patte noem hierdie grondstruktuur 'n semantiese wêreld (semantic universe) en verstaan dan onder universe die werklikheidsgebied wat deur 'n sisteem van oortuigings afgebaken is. Hierdie semantiese wêreld hou die gelowiges aan die lewe deur die lewe vir hulle betekenisvol te maak en deur 
hierdie betekenisvolle konteks dit vir hulle moontlik te maak om hulle identiteit te vind. Ook hier speel 'aanhangers-in-funksionering' dus 'n sleutelrol. Hierdie semantiese wêreld bepaal ook wat die gelowiges sê as hulle hulle oortuigings verwoord.

Daar is ' $n$ opmerklike verskil in vlak waarop die grondstrukture van Sanders (1977) en Patte (1983) funksioneer. Dié van Sanders funksioneer op die bewuste vlak. Hier is motiewe al duidelik geformuleer en hulle funksionering-in-verband duidelik omskryf. Patte se oortuigingspatroon funksioneer op 'n dieper vlak. Die gelowiges is nie bewus van die grondstruktuur waaruit hulle sekere keuses gemaak het nie. Grondliggend aan baie uitsprake van Paulus lê 'n beperkte getal oortuigings wat georganiseer is volgens 'n patroon.

In hierdie studie word die grondstruktuur wat motiewe dra, nie só diep gesien dat dit bar word soos by Boers (1984) nie. Aan 'n element van Boers se siening word besondere klemtoon gegee. Grondstruktuur moet altyd saam met die elemente of motiewe gesien word wat deur die grondstruktuur gedra word. 'n Teks kry betekenis vanuit uitsprake op die oppervlakte, dus uit die bewuste motiewe. Godsdienspatroon is die paradigma waarvolgens geloof in godsdiensuitlewing en teologie ontvou. Hierdie paradigma word nie saam met Sanders in die oppervlakte-motiewe gesoek nie. Die patroon wat oppervlakte-motiewe bind, is nie die grondstruktuur nie. Die grondstruktuur word ook nie so diep gesoek soos Boers (1984) doen nie. Die barre teenstelling dra nie veel by tot die konstruksie van godsdienspatroon nie. Aan die ander kant word daar dieper gesoek as Patte (1983) se oortuigingspatroon. Die 'dieper' bestaan daaruit dat gevra word wat die oortuigingspatroon en daarom ook die motiewe op die oppervlakte eintlik saambind. Hiermee word onderskei tussen 'n primêre en sekondêre binding van motiewe op die oppervlakte. Die primêre saambinder is die godsdienspatroon. Die sekondêre saambinder kan onder andere 'n bewuste teologiese oogmerk wees. Hier kan 'n paranetiese of didaktiese of een of ander oogmerk uitgewys word.

Geloof, lewe en teologie in 'n godsdiens funksioneer samehangend. Die faktor wat hierdie samehang bepaal, word die godsdienspatroon genoem. Die motiewe wat in 'n teologie op die oppervlakte figureer, het 'n sekere primêre samehang. Hierdie samehang word deur die godsdienspatroon bepaal.

'n Enkele element of ' $n$ sterk beperkte aantal elemente bind 'n godsdienspatroon saam. Patte (1983: 23) gee uitdrukking aan dieselfde gedagte wanneer hy sê dat hy sekere oortuigings in 'n oortuigingspa- 
troon meer grondliggend as ander beskou. Die semantiese wêreld, sê hy, brei voortdurend uit en plaas elke nuwe situasie in 'n raam, ooreenkomstig die patroon van sy kern wat 'n religieuse kern is. Patte (1983: 25) sien tereg in dat die kenmerkende van 'n geloof die patroon is wat deur die relasie van oortuigings in 'n samebondeling (cluster) gevorm word.

Dit is dus duidelik dat wanneer mens iemand wil 'bekeer', dit geen betekenis het om met hom in gesprek te tree oor los motiewe wat op die oppervlakte van beide gespreksgenote se oortuigings lê nie. Dit het net so min betekenis om aan hom 'n volledige dogmatiek van jou geloof voor te lê en van hom te vra dat hy op elk van die lokusse instemmend moet antwoord. 'Bekering' geskied op 'n dieper vlak. Hy moet die godsdienspatroon aanvaar wat grondliggend is aan jou godsdiens.

Patte (1983: 24) is van mening dat die oortuigingspatroon van 'n godsdiens gevestig word rondom dié elemente van die menslike ervaring wat die moeilikste bestaansprobleme vorendag bring ten opsigte van ' $n$ verstaan van die betekenisvolheid van menslike bestaan. Hierdie studie toon aan dat Paulus nie sy godsdienspatroon rondom sulke vrae gevestig het nie.

Hiermee het die vraag na die 'op grond waarvan' en die 'hoe' van die rekonstruksie van Paulus se godsdienspatroon na vore getree. Beide die omvang en kwaliteit van die konsensus dat Paulus se teologie net uit sy briewe afgelei behoort te word en dat Handelinge buite rekening gelaat moet word, bring mee dat sy briewe die eintlike bron vir die rekonstruksie van sy godsdienspatroon is. In dié studie word net die briewe as Paulinies aanvaar wat deur breë konsensus só aanvaar word. Uit die motiewe van Paulus wat hy in besondere omstandighede na vore gebring het èn uit sy optrede in besondere omstandighede, word sy godsdienspatroon afgelei. Die godsdienspatroon as 'geloofsinfra' dra die uitsprake en sy optrede in besondere omstandighede (vgl Lüdemann 1983: 20).

Daar sal in die konstruksie van Paulus se godsdienspatroon ook van 'n godsdienshistoriese vergelyking gebruik gemaak word. Hierdie vergelyking van parallelle sal sinkronies wees. Daar sal veral daarop gelet word of parallelle binne soortgelyke godsdienspatrone optree. Dit word beklemtoon dat hier nie na die metode van die godsdienshistoriese skool teruggekeer word waar 'n teks verklaar is teen die agtergrond van, vir Paulus kontemporêre, godsdienstige gedagtes nie (vgl De Villiers 1984: 67). 


\subsection{Trajekrekonstruksie se twyfelagtige bydrae tot interpretasie van betekenis}

Die besware teen ' $n$ metode wat veral diakronies toegang tot betekenis soek, is alreeds genoem. In hierdie paragraaf word 'n diakroniese poging kortliks bespreek. Die poging onder bespreking is nie net interessant omdat dit oud en besonder invloedryk is nie (Kim 1981: 162), maar veral omdat dit berus op die vooronderstelling dat Paulus rondom die motief wat ter sprake is, in 'n antitrajek dink. Die bespreking van dié poging sal ook later ' $n$ inset lewer wanneer Paulus se godsdienspatroon gerekonstrueer word.

Die gedagte dat Paulus se Adam-Christologie op 'n gnostiese oermenskonsep berus, is nie alleen oud nie, maar ook baie invloedryk (Kim 1981: 162). Daar word gemeen dat, terwyl Paulus se voorstelling as polemiek 'n kontratrajek met die gnostiese voorstelling vorm, die rekonstruksie van hierdie gnostiese trajek as agtergrond sal dien om Paulus te verstaan èn dat dit die oplossing sal bied vir dié probleme wat Paulus se Adam-Christologie inhou (Brandenburger 1962: 72 vv; 131-139; 140-143). Afgesien van die godsdienshistoriese misvatting in die rekonstruksie van die gnostiese opvatting (Käsemann 1980: 134 $\mathrm{v})$, is daar ook aangetoon dat hierdie diakroniese werkwyse die teks geweld aandoen (Kim 1981: $164 \mathrm{v}$ ).

Indien van die veronderstelling uitgegaan word dat die agtergrond van Paulus se denke eintlik sy eie godsdienspatroon is, lewer ' $n$ sinkroniese benadering van die Paulusteks bevredigender resultate as ' $n$ diakroniese benadering. Al sou Paulus polemies een of ander gedagtegang teenstaan, is die eintlike sleutel vir verstaan nog altyd in die eerste plek sy eie godsdienspatroon. Die grondstruktuur van 'n polemies-gebonde argument is nog altyd primêr sy eie godsdienspatroon. Die kontra-trajek waarvolgens hy betoog, is die sekondêre bindmiddel en kan daarom by interpretasie hoogstens 'n sekondêre rol speel.

Daar sal noukeurig vasgestel moet word of Paulus inderdaad so 'n anti-trajek as sekondêre bindmiddel gebruik het. 'n Wesenlike probleem is veral of die oorspronklike trajek herbou kan word. Mens staan hier weer voor die probleem dat die onbekende, 'Paulus se betekenis', deur 'n miskien nog onbekender trajek, 'gnostiese denke', verklaar word.

Hoe invloedryk die opvatting ook al is dat Paulus in Romeine 5 rondom Adam en Christus volgens 'n antignostiese trajek gedink het, aanvaar geleerdes hierdie teorie al hoe moeiliker (Käsemann 1980: 135; Kim 1981: 177). 
In hierdie studie word dit benadruk dat die vergelyking van los elemente van verskillende godsdienste nie baie sinvol is as hulle nie soortgelyke godsdienspatrone het nie. Die gemeenskaplike element 'Mens' bevestig ook nie noodwendig 'n afhanklikheid, 'n stroom-afverhouding of ' $n$ antitetiese polemiek nie. Dit is eerder godsdienspatrone wat vergelyk moet word (vgl Sanders 1977: 552).

Paulus se verlossingsmotief word in Romeine 5 gevorm deur die elemente Adam en Christus en wel so dat Adam en Christus antiteties teenoor mekaar staan. Christus word mens en hierdie mens is medebepalend vir verlossing. In die verlossingsmotief van die gnostiek is die hemelse Mens vasgevang in aardse materie en is verlossing juis die ontvlugting van die aardse materiële. In hierdie twee modelle van verlossing is daar dus te min element-ooreenkomste (as antiteses) wat dit moontlik sou maak om te beweer dat Paulus hier op 'n antignostiese trajek dink (Käsemann 1980: 135; Kim 1981: 178).

Wilckens (1978: $308 \mathrm{vv}$ ) beweer dat Romeine 5:12-21 verstaan moet word as Paulus se 'skerp polemiek' teen die gnostiese Mensmite. Dit is opvallend dat hierdie vooronderstelling baie min bydra tot Wilckens se interpretasie van hierdie gedeelte.

\subsection{Paulus se godsdienspatroon*}

Die grondstruktuur van Paulus se teologie word nie uit elemente van die menslike ervaring rondom moeilike bestaansprobleme gevorm nie. Die grondstruktuur van Paulus se denke is sy verkondiging van die lewende en ware God wat as die lewende en ware God erken moet word. Die godsdienspatroon van Paulus is hierdie grondstruktuur èn die oppervlakte-motiewe wat op hierdie grondstruktuur rus. Die grondstruktuur self is nie antiteties of polêr nie. Teenoor die lewende God staan dus nie 'nie-God' nie. 'Teenoor' die lewende God staan 'God nie ken nie' (1 Tess 4:5) of 'God nie eer en dank nie' (Rom 1:21). Die motiewe wat uit hierdie grondstruktuur op die oppervlakte ontwikkel word, is dikwels teenstellend. Teenoor die lewende en ware God tree die beelde (Rom 1:23) na vore óf die 'eerste beginsels van die wêreld' (Gal 4:3) of 'die dinge wat werklik geen-gode is nie' (Gal 4:8v). Hierdie 'nie-werklikhede' is alleen 'werklik' omdat hulle in slawerny gedien word.

Die godsdienspatroon van Paulus lê nie stroom-af in die vloei van 'n groter Hellenistiese godsdienstige kultuur nie. Sy godsdienspatroon lê

* Kyk Bylae: Die ontstaan van 'n Paulusteks, bladsy 376. 
ook nie stroom-af in die vloei van een of ander Judaïstiese beweging van sy dag nie.

Dat daar elemente in Paulus se oppervlakte-motiewe is wat sterk ooreenkoms met uitsprake van beide godsdienste vertoon, is duidelik. Hierdie parallelle-voorkoms bied min hulp vir die interpretasie van betekenis by 'n Paulusteks. Dit is eenvoudig so omdat die godsdienspatroon, en veral die grondstruktuur van Paulus, wesenlik verskil van hierdie bogenoemde twee godsdienste. Die grondstruktuur van Paulus se denke en lewe is nie die universele dilemma van die mensdom nie (vgl Boers 1984: 133 v). Dit word duidelik as daar na Paulus se ontwerp van teenstellings op die oppervlakte gekyk word. 'n Mens sou geneig wees om dood en kwaad teenoor lewe en die goeie te stel. In Paulus se godsdienspatroon is dié polariteit nie só eenvoudig nie. Dood is nie 'n vanselfsprekende gevolg van kwaad/boosheid nie. Agter hierdie 'verband' lê 'n daad van die lewende God. Hy wat God nie ken nie, word juis hierom deur begeerte en hartstog gedryf ( 1 Tess $4: 5)$. Juis dié mense wat God nie eer en dank nie en beelde maak, word deur God oorgegee aan sedelike onreinheid (Rom 1:24 vv). Die dominante rol van die lewende God is hier in die oppervlakte-motiewe baie duidelik. Ook die pool goed/lewe is nie eenvoudig nie. Die goeie lei nie na die lewe nie. Omdat lewe 'n geskenkdaad van die lewende God is, lei lewe na die goeie ( $\operatorname{Rom} 6: 10$ ). Wanneer lewe ewige lewe beteken, tree die lewende God ook na vore as dié God wat die ewige lewe as genadegawe gee. Omdat die lewende God telkens in die oppervlaktemotiewe die dominant is, is dit redelik om hieruit af te lei dat 'die lewende God' ook in die grondstruktuur 'n dominante rol speel.

Die gevaar is groot om die betekenis van 'n Paulusteks mis te vat as sy denke bloot op sistematiese wyse in lokusse beskryf word. Paulus dink nou eenmaal net nie in geïsoleerde lokusse nie en hy bied ook nie sulke geïsoleerde gesistematiseerde lokusse aan nie. Natuurlik is daar motiewe wat 'n duidelike reliëf het en wat met 'n dogmatiese lokusaanduiding beskryf kan word. Hierdie motiewe is egter altyd met een, en meer dikwels met meer ander motiewe vervleg. Al is dit dus nie onwettig om gebruik te maak van dogmatiese lokusse in die omskrywing van Paulus se godsdienspatroon nie, moet hierdie dogmatiese kategorieë eerder as aanduiding van temas verstaan word. Hiermee word nie bedoel dat temas by Paulus nie 'dogma' inhou en dus nie normatief is nie (vgl Gal 6:16 v; 1:6, 8, 9; 1 Tess 4:8).

Paulus se briewe het nie die karakter van 'n geykte dogmatiek nie, maar eerder dié van preke. In sekere omstandighede motiveer hy an- 
ders, formuleer hy anders en beklemtoon hy anders as in ander omstandighede. Tog dink hy konsekwent. Die rede hiervoor is dat sy lewe en denke deur sy godsdienspatroon gedra word.

\subsubsection{Teo-logie}

Dit is opvallend dat Paulus nie 'n tema oor God selfstandig, dit wil sê los van ander temas, uitwerk nie. Hierdie afhanklikheid van ander temas van die tema oor God is self 'n element van sy godsdienspatroon. Die vooronderstelling van 'n grondstruktuur waarin die 'lewende God' dominant is, lewer 'n bevredigende inset om die betekenis van temas op die oppervlakte te interpreteer. Dit is so veral omdat die primêre bindfaktor tussen die temas en motiewe op die oppervlakte hierdeur uitgewys word.

Dit is verder opvallend dat ook in die grondstruktuur nie God se 'wese' nie, maar 'God-in-handeling' op die voorgrond staan. Om hierdie rede dink Paulus nie eintlik in ontologiese kategorieë nie, maar in dinamiese kategorieë, soos die motiewe op die oppervlakte van die teks duidelik aantoon. Omdat Paulus vanuit 'n dinamiese grondstruktuur dink, word die aard van sy boodskap beter beskryf as prediking. Alhoewel Paulus met geykte motiewe en begrippe werk, het sy temas nie in lokusse gestol nie.

In die volgende twee paragrawe word aangetoon dat die elemente die lewende God en die erkenning van God as die lewende God, die grondstruktuur van Paulus se godsdienspatroon vorm. In die eerste plek word daar gefokus op 1 Tessalonisense en veral op die makrostruktuur van die brief. In die tweede plek word ' $n$ dwarssnit van Paulus se briewe gedoen aan die hand van die motief dóxa tô theô.

\subsubsection{Grondstruktuur van die godsdienspatroon en 1 Tessalonisense}

Die uitsprake oor God op die oppervlakte van die brief is die volgende:

1:1 Die gemeente behoort aan God

God is God, die Vader

1:2 ons dank God

$1: 3$ ons vra God

God is ons Vader

1:4 God kies hulle wat Hy liefhet, uit

1:8 julle glo in God 
1:9 julle het julle tot die lewende en ware God bekeer om Hom te dien

1:10 God het sy Seun uit die dood opgewek

2:2 ons God gee ons moed om die evangelie van God te verkondig

2:4 God het ons gekeur ons stel God tevrede

God ken die diepste gedagtes

2:5 God is ons getuie

$2: 8,9$ die evangelie van God

2:10 God is ons getuie

2.12 leef tot eer van God

2:13 ons dank God die boodskap van God ( 3 keer)

2:14 God se gemeentes

2:15 die wil van God

2:16 die toorn van God

$3: 2$ in diens van God

3:9 ek dank God

3:11 mag God self die pad na julle oopmaak heilig en onberispelik voor God ons Vader

4:1 leef ooreenkomstig God se wil

4:3 God wil dat julle heilig lewe

4:5 die heidene ken God nie

4:7 God het ons geroep om heilig te lewe

4:8 hy wat hierdie voorskrifte verwerp, verwerp God

4:9 julle is deur God geleer om mekaar lief te hê

4:14 God neem Jesus na Hom toe

God sal die ontslapenes na Hom toe neem

4:16 God gee bevel dat sy trompet geblaas word

5:9 God het ons bestem om verlos te word

5:16 God verwag dankbaarheid

5:23 ons bid tot God

God maak julle toegewyd

God bewaar julle om onberispelik te wees

5:24 God is getrou.

Hierdie uitsprake op die oppervlakte is 'n aanduiding van die makrostruktuur van dié brief. Hulle is egter ook aanduiding van die grond- 
struktuur van Paulus se teologie en lewe. Aan die wortel van hierdie uitsprake lê twee elemente: God is lewend en die lewende God moet erken word. Dat God lewend is, loop uit op motiewe soos God is ons Vader en ons behoort aan Hom; Hy is die God wat liefhet, uitverkies, sy Seun uit die dood opwek; Hy dra self sy evangelie; God ons Vader eis van ons, roep ons; die toorn van God en God sal ook die ontslapenes na Hom toe neem. Die element dat God erken moet word, lê aan die wortel van die motiewe soos God word gedank, gedien, sy evangelie word verkondig en tot sy eer leef ons heilig.

Die uitspraak dat God die lewende God is en dié oor die motiewe wat hieruit voortspruit, dra die temas rondom Jesus Christus en die Heilige Gees. Hierdie temas is op hulle beurt vervleg met die temas oor verlossing, wederkoms, heilige lewe en 'n lewe in liefde vir mekaar (vgl $1: 1,2 ; 1: 4 ; 1: 10 ; 3: 12 ; 4: 14 ; 5: 9)$.

Die dinamiese aard van Paulus se Godsvoorstelling is dus deel van sy grondstruktuur en sy godsdienspatroon. Dat dié grondstruktuur nie bloot 'toevallig' is en dus net aan die makrostruktuur van 'n vroeë brief verbonde is nie, blyk duidelik as 'n dwarssnit deur al die Paulusbriewe gemaak word.

\subsubsection{Dóxa toû theoû}

Die dinamiese aspek van Paulus se Teo-logie tree veral na vore rondom die term dóxa tôu theoû. As voorbeeld hiervan word verwys na Romeine 1:18-23. In hierdie perikoop skakel dié term struktureel met 'God openbaar sy toorn'. Semanties kry dié term betekenis uit die resiproke verhouding met toorn van God, God openbaar, God skep, God het mag en God gee oor. In die dieptestruktuur van 1:18-23 speel dóxa toû theôu 'n sleutelrol. God maak sy doxa bekend in sy skeppingsmag. God se dóxa word deur Hom openbaar as sy onverganklikheid, maar veral openbaar Hy hom deur sy lewende optrede. Dat Hy die lewende God is, sal die wat Hom as 'n verganklike skepsel afbeeld, weet as hulle sy dóxa ook as sy toorn beleef. Die beklemtoning van God as 'n dinamiese, lewende, lewegewende en nuutskeppende God tree ook duidelik na vore in Romeine $3: 7 ; 3: 23 ; 4: 20 ; 5: 20 ; 6: 4 ; 8: 18 ; 9: 4 ; 9: 22 ; 11: 36$. Ook in Romeine 15:7-13 speel die begrip dóxa tô theoû in die dieptestruktuur 'n sleutelrol om God se betroubaarheid, sy soewereine ontferming en mag te onderstreep.

As Wilckens (1978: 107) God se dóxa beskryf as 'die lig en krag stralende atmosfeer van sy teenwoordigheid, sy onverganklike identiteit met Homself, sy "eer", wat Hy as die Skepper aan sy skepsels 
meedeel', sien hy die wesenlike van God se dóxa as God se eie dinamiek nie sterk genoeg raak nie. Die 'ontologiese konnotasie' (Pelser 1982: 110) staan nie op die voorgrond nie, maar die dinamiese.

Paulus gee veral in die Romeinebrief reliëf aan God se dinamiek deur die begrip dóxa. Die dinamiese aspek van dié begrip se verwysing tree ook na vore in 2 Korintiërs $(3: 18 ; 4: 6 ; 4: 15)$. Ook in 1 Tessalonisense kry die dinamiese van God se dóxa betekenis deur die resiproke verhouding met 'God roep' en God se koninkryk. Die sterk resiproke verhouding tussen dóxa en koninkryk van God is al meermale raakgesien (Schneider 1932: 91; Ellingworth en Nida 1976: 35). Die verwysingsveld vir dóxa is dus telkens dinamies.

Die vraag kan op hierdie stadium gevra word of 'n diakroniese vooronderstelling kan bydra tot die interpretasie van die betekenis van Paulus se Teo-logie. Die probleem is hier dat ' $n$ moontlike parallel uit so ' $n$ verskillende godsdienspatroon kan spruit dat alle parallellisme verdwyn. By Filo ( $Q$ in Ex) is 'n enkele moontlike parallel van Paulus se gebruik van dóxa. Filo vergelyk God se magtige teenwoordigheid op Sinai met die dóxa en dúnamis van 'n koning. Hier dink Filo veral dinamies. Filo se godsdienspatroon is egter só ontologies bepaald dat hy die God van die Ou Testament kon aanpas by die godsvoorstelling van die Griekse filosofie. Dít geld ook van Josefus (Dahl 1977: 181; vgl Bultmann 1958: 70).

Dit is te verwagte dat Paulus in 'n Hellenisties-heidense omgewing die Teo-logie sou beklemtoon (1 Tess 1:9; 1 Kor 12:2; Gal 4:8; vgl Bultmann 1958: 71). Dat hierdie situasie die impuls vir Paulus se godsdienspatroon was, is ' $n$ ope vraag. Paulus se godsdienspatroon is uniek (Sanders 1977: 555). Hierdie uniekheid tree veral na vore in sy motief oor God. Palestyns-Joodse, Hellenisties-Joodse of Hellenistiese opvattings oor God speel nie 'n aanwysbare rol in sy godsdienspatroon nie. Dat veral die motiewe oor God binne 'n godsdienspatroon optree, blyk daaruit dat die Griekse monoteïme deurloop na 'n kosmologie (Dahl 1977: 181; Bultmann 1958: 70). Die vermoede dat Filo en Josefus by 'n Grieks-Hellenistiese godsdienspatroon aangesluit het, word waarskynlik as hulle God se wêreldheerskappy op die voorgrond stel: God is die God van die heelal en van alle mense.

By Paulus loop die Teo-logie deur na die Christologie en verlossingsmotiewe. Paulus se universalisme word duidelik gekwalifiseer deur veral die uitdrukkinge 'deur die geloof' en 'in Christus' (vgl Güttgemanns 1971: $97 \mathrm{v}$ ).

Ook die Palestynse Jodedom het 'n gekwalifiseerde universalisme 
geleer. Ook hierdie universalisme is deel van hulle godsdienspatroon. God is veral die God van Israel, maar as God van Israel ook God van alle mense (Dahl 1977: $185 \mathrm{vv}$ ). Die rabbyne het partikularistiese en universalistiese uitsprake langs mekaar gehandhaaf. Die konsepte uitverkiesing en verbond wat in die Palestynse Jodedom se godsdienspatroon duidelik voorkom, het nie die uitsprake oor 'n universele monoteïsme weerspreek nie. Die rabbyne het die geopenbaarde Tora geïdentifiseer met die wysheid van God en as sodanig met die skeppingsbeginsel en met die kosmiese wêreldorde self (Dahl 1977: 188). Wanneer die rabbyne dus sê dat God die Skepper en Regter ook van die heidene is, onderskei hulle nie tussen God se verbondsoptrede en sy skeppingsoptrede nie. Ook wanneer God die God van Israel genoem word, is Hy die God van die heidene omdat Hy deur die Tora Hom as God handhaaf en beslag lê op die skepping. Vermoedelik het Kronistiese motiewe hier 'n rol gespeel (vgl Engelbrecht 1985: 122).

Oppervlakkig beskou, lyk dit of Paulus in Romeine 3:27-31 by hierdie rabbynse opvatting oor die 'Een God' aansluit. Die dieptestruktuur van hierdie gedeelte maak dit duidelik dat ons hier nie 'n universalisme het wat op 'n ontologiese Godsverstaan berus nie. Hier figureer 'n dinamiese Godsvoorstelling in die dieptestruktuur wat uitloop op 'n ekklesiologiese tema. Deur sy soewereine krag (dóxa tôे theoû) openbaar God dat Hy sonder die wet regverdig maak. Dit doen Hy deur almal te regverdig wat in Jesus Christus glo. God se soewereine krag omvat dus sy geregtigheid, sy genade en sy vergewing. Hierdie gawes van God word vir hulle wat in Jesus Christus glo, werklik. Ten spyte van die synsbegrippe wat op die oppervlakte 'n rol speel (dóxa tô theós), word hierdie gedeelte (3:27-31) gedra deur'n dinamiese motief oor God waarin die 'God is Een' en 'glo in Jesus Christus' fundamenteel is. Paulus beklemtoon die 'universaliteit' van die geloofsgeregtigheid vir Jode en heidene. 'God het sy enigheid daarin bewys deurdat $\mathrm{Hy}$ as die Een almal regverdig, die peritomē word ek pisteōs regverdig net soos wat die akrobustía, diá pisteōs regverdig word' (Wilckens 1978: 248). Paulus se universalisme word in 3:27-31 deur 'deur die geloof' en deur die ekklesiologiese tema gekwalifiseer.

Paulus se motiewe oor God en sy universalisme tree dus duidelik binne 'n eie godsdienspatroon op. Ten spyte van terminologiese ooreenkomste tussen Paulus en die Palestynse Jodedom, veral rondom die Teo-logie, tree hierdie 'parallelle' in twee heeltemal verskillende godsdienspatrone op en verskil hulle verwysingsveld ook dus radikaal. Veral Sanders (1977: 552) het beklemtoon dat 'ten spyte van ooreen- 
komste Paulus se godsdienstipe grondig anders is as enige iets wat bekend is van die Palestynse Judaïsme'.

Die grondige andersheid van Paulus se godsdienspatroon berus op sy Teo-logie wat die grondstruktuur van sy motiewe en temas vorm. Die dinamiek van hierdie grondstruktuur maak dit waarskynlik dat hy op 'n Ou-Testamentiese motief steun. Von Rad (1960: 245) het op 'n parallelle dinamiese motief gewys in die teologie van sommige Psalms, by die Priesterbron en by Esegiël. In bogenoemde gevalle 'handel dit om 'n openbaarwording as die beslissende verwerkliking van God se heerskapaanspraak op die wêreld en gaan dit nie eintlik om die wese van God "an sich" nie'. Dat Paulus 'n Ou-Testamentiese motief oorgeneem het, word hoogs waarskynlik as in ag geneem word dat ook Jesaja en Deutero-Jesaja God se 'heerlikheid' koppel aan 'n eskatologiese heilsdaad van God waarin die allesomvattendheid van dié daad op die voorgrond staan.

'n Verdere vraag wat met betrekking tot Paulus en sy moontlike agtergrond gevra word, is of sy godsdienspatroon nie radikaal van dié van sy tradisie verskil nie. Hoe sterk Paulus ook al 'my evangelie' (Rom $2: 16 ; 16: 25$; Gal 1:11) beklemtoon, het hy daarmee nooit bedoel om wat die inhoud van sy evangelie betref, 'n prinsipiële grens tussen hom en die tradisie te trek nie. Daar is beduidende konsensus onder die navorsers dat Paulus in Romeine 1:3 vv; 3:24 vv; 4:25; 15:3 en Filippense 2:5-11'n vroeë tradisie aanhaal (Kahl 1977: 24). Paulus haal ook oorgelewerde Jesuswoorde aan (1 Kor 7:10; 9:14; 1 Tess 4:15). Paulus handhaaf dus ' $n$ kontinuïteit met die vroeë tradisie. Tog is Paulus se briewe van die vroegste getuies dat die vroeë Christelike godsdiens die oorlewering nie as 'n gestolde siteervoorbeeld gesien het nie, maar as 'n verkondigingsvoorbeeld. Wanneer Paulus sy tradisie of die Ou Testament aanhaal om sy prediking te ondersteun, plaas hy hierdie aanhalings in ' $\mathrm{n}$ selfstandige tema. Dieselfde evangelie word in omstandighede wat verskil, nuut geformuleer en opnuut dringend gemaak.

Dit is opvallend dat juis dié dele van Paulus se tradisie waarop hy steun, deur 'n sterk dinamiese Godsvoorstelling gedra word. Hierdie gedeeltes ontleen hulle dinamiek aan hulle eng verbintenis met 'n Christologie waarin God Christus as versoening gee (Rom 3:24-26) en God Christus opwek 'sodat ons vrygespreek word' (Rom 4:25; vgl Fil 2:9-11; Rom 1:3 vv).

Het Paulus by 'n ou tradisie aangesluit (vgl Wilckens 1978: $56 \mathrm{vv}$ ) en sy evangelie vir 'n Hellenistiese situasie aangepas? Veral Bultmann (1958: 69) beklemtoon dat die Christelike sendingprediking in die hei- 
denwêreld nie eenvoudig net 'n Christusprediking kon gewees het nie - dit moes eerder begin met die verkondiging van die Een God in 'n omgewing waar die meer-godedom vanselfsprekend was. Hierom maak Paulus van Hellenisties-Stoïsynse terme gebruik in Romeine 11:36 en 1 Korintiërs 8:6 (Bultmann 1958: 74).

Indien egter in gedagte gehou word dat Paulus eerder die dinamiese van God as sy wese en Goddelikheid beklemtoon, is hierdie diakroniese verklaring vir Paulus se Teo-logie nie heeltemal bevredigend nie. Teenoor sy Hellenistiese omgewing, maar ook teenoor die Judaïsme van sy dag, beklemtoon Paulus God se optrede en dinamiek eerder as God se 'syn'. Die ontologie tree op die agtergrond. Hy maak veral van Ou-Testamentiese voorstellings (vgl Wilckens 1978: 107) gebruik om God se enigheid en dinamiek af te grens teenoor die veelheid en beweginglose onmagtigheid van mensgemaakte gode (vgl Rom 1:23 vv waar Ps 106:20, Jer 2:11 en Deut 4:15-18 'n beduidende rol speel; vgl ook 1 Kor 8:5 v en 1 Tess 1:9 v). Is dit veral sy 'nuwe' omgewing wat Paulus só laat beklemtoon? Die Hellenistiese omgewing sou wel tot hierdie gedetailleerde formulering bygedra het.

Paulus sal egter beter verstaan word vanuit sy eie godsdienspatroon as vanuit ' $n$ godsdienserfenis of ' $n$ polemiese motief teen die agtergrond van 'n Hellenistiese omgewing. Die Paulusteks is uiteindelik die produk van 'n skrywer wat vanuit 'n eie godsdienspatroon skep. Hierdie patroon is ' $n$ selfstandige grootheid. Alhoewel elemente van dié patroon erfgoed van sy tradisie mag wees, kry hulle in hulle nuwe samehang 'n nuwe, of minstens 'n nuut beklemtoonde betekenis.

Alhoewel dit moontlik is dat Paulus se besondere beklemtoning van die Teo-logie ' $n$ voortsetting van die Hellenistiese Jodedom se propaganda was (Bultmann 1958: $71 \mathrm{v}$ ), is dit juis uit die voorbeelde wat Bultmann aanhaal, duidelik dat in dié Joodse propaganda die ontologiese aspek die klem dra en nie die dinamiese nie. Hierteenoor beklemtoon Paulus die dinamiese in sy Teo-logie, selfs in die gedeeltes waar die ontologiese aspek, wat die oppervlak-struktuur betref, op die voorgrond staan (Rom 3:30; 1 Kor 8:4 vv; 1 Tess 1:9; (Rom 16:27); vgl Rom 9:26; 2 Kor 3:3).

\subsubsection{Christologie}

Juis omdat die dinamiese in Paulus se godsdienspatroon op die voorgrond staan, is sy temas nie 'n spekulatiewe sisteem oor die 'syn' nie. Bultmann (1958: $191 \mathrm{v}$ ) is reg as hy stel dat Paulus se teologie nie 
geïsoleerd oor God se wese handel nie, maar alleen ontvou rondom die betekenis van God se wese vir die mens, sy verantwoordelikheid en sy heil. Bultmann is ook reg as hy stel dat in dié sin teologie antropologie, en Christologie soteriologie is. Dit is egter'n ope vraag (vgl Käsemann 1972: 27) of Paulus se teologie die beste verstaan sal word wanneer dit as mensleer ontwikkel word (Bultmann 1958: 192).

Die Teo-logie as grondstruktuur van Paulus se lewe en denke ontvou in temas rondom Christus en verlossing (vgl Fil 2:6-11). Ook in die motiewe op die oppervlakte is die motief van die lewende God dikwels met ' $n$ Christusmotief verbind. In Romeine 15:7-13 is die tema die eenheid van die kerk waarin swakkes en sterkes, Jode-Christene en heiden-Christene is. Hierdie tema word gedra deur 'n noue samehang van motiewe oor God en Christus. Die grondstruktuur van Paulus se godsdienspatroon is hier die draer van die motiewe en die tema. Hierdie gedeelte (15:7-13) se progressie verloop dan tussen God se soewereine mag wat uitdrukking vind in die motiewe 'God se betroubaarheid' en 'God se ontferming', tot by die alomvattendheid van die lof aan God. Hierdie progressie word gedra deur die Christusmotief. Christus neem die gemeente aan uit Jode en heidene en sý dienswerk bevestig God se betroubaarheid en ontferming.

Die dinamiese aspek van Paulus se Teo-logie loop deur na sy Christologie. Soos God se identiteit veral duidelik word uit sy optrede, so word Christus se identiteit ook uitgedruk deur wat Hy doen. Ook Boers (1984: 142) het daarop gewys dat die 'figuratiewe trajekte' (buitelyne van besondere motiewe in hulle verband) wat uitdrukking gee aan Christus se identiteit, in Paulus se briewe relatief min is. Hy stel dan dat Christus se betekenis by Paulus te vind is in die rol wat Christus vul.

Net soos hy God se dinamiek onderstreep, beklemtoon Paulus ook Christus se dinamiese optrede deur dié begrip. Dit is só omdat Christus die heerlikheid van God uitstraal ( 2 Kor 4:4 vv). Soos God se dóxa sy skeppingsmag is wat lig uit die duisternis laat skyn het, so het God deur Christus, omdat God se skeppingsmag uit Christus uitstraal, sy gemeente uit die duisternis na die lig toe oorgebring (vgl Fil 3:21; vgl Schneider 1932: 100).

Die Christologie funksioneer in Paulus se godsdienspatroon nie slegs as 'n 'langs God' nie (vgl Bultmann 1958: 81), maar Christologie is Teo-logie in beweging. Hierdie paragraaf kan saamgevat word met ' $n$ aanhaling uit Schneider (1932: 105) dat dóxa by Paulus " $n$ dinamiese karakter in dié dubbele sin het dat in die dóxa die mag van God en van 
Christus openbaar word èn dat die dóxa werk, ja, heil bewerk'. Hierdie skeppende en heilskeppende dinamiek van God deur Christus is die hart van Paulus se godsdienspatroon.

\subsubsection{Verlossing en mens}

Dit is reeds gestel (2.3.1) dat wat die inhoud van sy evangelie betref, Paulus nie 'n prinsipiële grens tussen hom en die oergemeente getrek het nie. Ook wanneer hy beklemtoon dat heidene nie besny mag word nie, doen hy moeite om duidelik te maak dat hy in dié opsig nie eiesinnig leer nie, maar só verkondig met instemming van die oergemeente (Gal 1:11-2:10; 1 Kor 15:3-15; vgl Kahl 1977: 14, 17 vv).

Paulus se opvatting oor die verlossing vir die Jode en heidene het nie van dié van die vroeë gemeente verskil nie. Die opvatting van die vroeë gemeente word goed weerspieël in die gelykenis van die wingerdeienaar en sy deelboere (Mark 12:1-9/Matt 21:33-46). Alhoewel Bultmann (1979: 191) van mening is dat die gelykenis nie anders as 'n allegorie verstaan kan word nie, en beide Markus en Matteus (veral) die gelykenis allegories omraam het, is die gedeelte net so goed as 'n gelykenis verstaanbaar. Vanuit die allegoriese aard en inhoud besluit Bultmann dat die gedeelte gemeenteskepping was. Dat die gedeelte egter net so goed as 'n gelykenis verstaan kan word, dui op 'n relatief vroeë ontstaan. Reeds vroeg in die geskiedenis van die Palestynse gemeentes het die opvatting geleef dat toe die Jode Jesus verwerp en doodgemaak het, God die heidene as sy volk aangeneem het. Die element van hierdie opvatting wat hier beklemtoon word, is dat die geskiedenis in twee fases verloop het - eers die verkondiging aan Israel en toe aan die heidene. Die tweede fase het God in werking gestel toe die eerste gewelddadig deur Israel verwerp is. Dat Matteus hierdie gelykenis tot allegorie omgebou het en juis hierdie fase-element gedetailleer het (Engelbrecht 1985: $83 \mathrm{vv}$ ), dui daarop dat hierdie fase-interpretasie van die gelykenis redelik algemeen was.

Paulus se opvatting oor Israel lê in die ontlening van hierdie vroegChristelike tradisie (1 Tess 2:14-16; Steck 1967: 274 v). Paulus se gevolgtrekking in hierdie gedeelte is dat God se toornige oordeel nou uiteindelik oor die Jode voltrek is (Ellingworth \& Nida 1976: 45). Hy maak hier nie 'n 'anti-Joodse uitspraak' nie (Dahl 1977: 137). Hierdie uitspraak is tipies van die Deuteronomistiese denke van Paulus se tyd oor Israel (vgl Steck 1967: 60-80). Paulus is dus nie hier besig om die Jode wat die sending betref, totaal af te skryf nie. Hy beskryf die breuk 
in die geskiedenis: God het die evangelie nou ook aan die heidene laat verkondig.

Hierdie Deuteronomistiese motief tree egter by Paulus nie dikwels (vgl Rom 10:19) op die voorgrond nie (vgl Engelbrecht 1985: 63 v). In 'n Hellenistiese omgewing lê hy die klem anders wanneer hy oor die Jode en die heidene praat. Elemente wat hier op die voorgrond tree, is dat God op grond van sy ontferming vir Hom 'n volk uit die Jode ěn die heidene geroep het (Rom 9:15, 16; 9:23; 11:30 vv). Hiermee tree 'n gekwalifiseerde universalisme na vore. God se Naam moet oor die hele wêreld verkondig word (vgl Rom 9:14-18). God ontferm Hom oor almal (Rom 3:27-31; 11:25-36) en dit moet uitloop op 'n omvattende lof aan God (Rom 9:17; 11:36; 15:9-11).

In die roeping van almal beklee Israel egter 'n besondere eerste plek (Rom 1:16; vgl 9:24). In die Romeinebrief stel Paulus dit baie duidelik dat God se verkiesing van Israel noodwendig is om God se regverdiging van Jode en heidene deur die geloof te verstaan (Boers 1982: 5; vgl Rom 1:16; 11:18).

Dit is van die grootste belang om duidelik raak te sien dat vir Paulus die beloftes aan Abraham óór Christus in die kerk deurloop - ook vir die Jode. Die verbonde wat met die Israeliete gesluit is (Rom 9:1-5), berus op God se belofte, nie op 'n blote nakomelingskap nie (Rom 9:6-13). Buite hierdie belofte bestaan net nog God se oordeel (vgl Rom 9:13, 17, 18, 22, $27 \mathrm{vv}$; vgl Brandenburger 1985: $25 \mathrm{v}$ ). Dit is opvallend hoe juis in Romeine 9 Paulus se argumentasie rondom Israeliete en Jode sterk Teo-logies onderbou is $(9: 4,6,7,8,9,13,14,15,16,17,18)$. 'God se soewereine vrymag' vorm die dieptestruktuur van Romeine 9:6-13 (vgl Brandenburger 1985: 33). Dit is tipies van Paulus se denke om motiewe Teo-logies te onderbou. Diě fundering van motiewe kom nie net na vore in Romeine 9 nie (vgl Rom 1:18-23; 2 Kor 4:6; 1 Tess 2:12).

Paulus se denke rondom lewe, verlossing en die doen van die goeie het ' $n$ besondere karakter. Paulus dink hier nie Tannaïties of in die verlenging van een of ander Judaïstiese gedagterigting nie (vgl Sanders 1977: 555). Dit is veral Paulus se denke rondom verlossing en die doen van die goeie wat ' $n$ vraagteken plaas agter stellings dat Paulus die gemeente sien as 'n verlenging van die Joodse gemeente (vgl Lüdemann 1983: 15) en dat Paulus nog altyd binne die Jodedom gebly het (Davies 1977: 4). 


\subsubsection{Die onlosmaakbaarheid van geloof en lewe}

Paulus se godsdienspatroon is nie 'n spekulatiewe sisteem oor die 'syn' nie. Daar is reeds aangetoon dat Paulus nie praat oor God op 'n statiesontiese wyse nie, maar op 'n dinamiese wyse. Hierdie dinamiese Teologie het uitgeloop op Christologie en soteriologie èn op die klem op die lewe van die gelowige.

Bultmann (1958: 328) het tereg daarop gewys dat die term en Christō by Paulus nie verwys na ' $n$ individuele mistieke Christusverhouding nie (A Schweitzer), maar na ' $n$ bepaalde individuele historiese lewe van die gelowige wat uit God se heilsdaad lewe. Romeine 15:7-13 is een van baie gedeeltes waar 'geloof' en lewe eng vervleg is. Hier loop Teo-logiese, Christologiese en ekklesiologiese motiewe uit op etiese vermaning (vgl Gal 2:15-21; Fil 2:1-11; 1 Tess 4:13-5:11). Bogenoemde gedeeltes is ' $n$ aanduiding hoe Paulus se etiek gesteun word deur' $n$ breë spektrum van motiewe.

Paulus se etiek funksioneer binne sy godsdienspatroon. Tussen sy etiek en die ander motiewe van sy godsdienspatroon is daar ' $n$ relatiewe verband. Sy etiek tree dus nie as 'n losstaande, verbandlose model op nie. Alhoewel Paulus sy betoog dikwels eties toespits, en etiese vrae dikwels 'n baie opvallende plek beklee, word sy etiek bepaal deur die verband van die etiek met die ander motiewe in sy godsdienspatroon.

In hierdie 'verband' speel die Teo-logie en die Christologie 'n dominante rol. Omdat Paulus se godsdienspatroon organies funksioneer, kan ' $n$ enkele motief nie los van sy verband met die ander motiewe verstaan word nie.

Paulus se motiewe het samehang op die oppervlakte, omdat hulle deur die grondstruktuur gedra word. Daar is reeds daarop gewys dat hierdie grondstruktuur twee elemente bevat, naamlik dat God die lewende God is en dat God as die lewende God erken moet word. Dié struktuur bied ' $n$ verklaring vir die samehang van motiewe, maar veral vir die voortdurende vervlegting van motiewe in die godsdienspatroon met die etiek. Käsemann (1972: 56) het daarop gewys dat dit 'n skeeftrekking van Paulus is om een motief in sy teologie te laat domineer. ' $n$ Voorbeeld van so ' $n$ interpretasie vanuit ' $n$ enkele motief is $H$ Braun wat Paulus vanuit ' $n$ antropologie interpreteer. Hierdie interpretasie hou nie rekening met die vervlegting van motiewe op die oppervlakte nie, maar hou veral nie rekening met die grondstruktuur van Paulus se lewe en denke nie. In die interpretasie van Paulus uit die hoek van die antropologie is Jesus weer besig om te werk wanneer medemenslikheid 
na die voorbeeld van Jesus beoefen word. Tereg sê Käsemann (1972: 49) van hierdie interpretasie dat waar die kúrios tot Exempel en voorbeeld word, is ook die Pauliniese antropologie onduldbaar gereduseer en vals georiënteer. Daar het egter veel meer gebeur. 'n Ander godsdienspatroon is onder Paulus ingeskuif. Die grondstruktuur van hierdie godsdiens is die nood van die menslike bestaan. Die motiewe van hierdie godsdienspatroon is lewe na die voorbeeld van Jesus. As in gedagte gehou word dat godsdienspatroon in hierdie studie omskryf word as grondstruktuur èn die motiewe wat hierdeur gedra word, is dit veral uit die motiewe van $\mathrm{H}$ Braun duidelik hoe wesenlik sy godsdienspatroon van dié van Paulus verskil.

\subsubsection{Samevatting}

Selfs hierdie beperkte ondersoek na Paulus se godsdienspatroon het die selfstandigheid van sy denke na vore gebring. Alhoewel hy uit baie en verskillende agtergronde leen, is nie ' $n$ enkele een van hierdie leengoed bepalend vir sy eie godsdienspatroon nie. Al gebruik hy Hellenisties-Stoïsynse terme om God as Skepper en wêreldheerser te beskryf, funksioneer hierdie terme binne 'n Teo-logie wat wesenlik anders is. Die navorsing plaas ook al hoe meer vraagtekens agter pogings om Paulus se opvatting van die mens te sien as reaksie op gnostiese misvattings wat in die gemeentes geleef het. Die ondersoek van veral EP Sanders (1977) het aangetoon dat Paulus se godsdienspatroon verskil van dié van die rabbyne en Judaïstiese newestrominge. Die Deuteronomistiese denke wat by $Q$ en Matteus ' $n$ prominente rol speel, speel by Paulus geen konsekwente rol nie (vgl egter Rom 10:19; 1 Tess 2:14 v).

Veral wanneer Paulus oor Jode, heidene en die kerk dink, is dit moeilik om te sê ten opsigte van watter gedagtepatroon hy stroom-af dink. Op ' $n$ unieke wyse word hierdie motiewe by Paulus gedra deur 'n dinamiese Godsvoorstelling wat versmelt is met 'n dinamiese Christologie. Dit is veral die dominante rol van Paulus se Teo-logie in sy godsdienspatroon wat dit moeilik maak om saam met Bultmann te aanvaar dat Paulus se prediking 'n voortsetting was van die beklemtoning van die Hellenistiese Jodedom se propaganda. Dit is ook ' $n$ ope vraag of die generiese impuls van Paulus se denke in 'n Hellenistiese situasie gesoek moet word.

Boers (1984: $137 \mathrm{v}$ ) het aangetoon dat daar in die motiefbane (figurative courses) en temas rondom Christus in Paulus se briewe ' $n$ duidelike polariteit is. Hierdie pole is lewe/dood en ook goed $/ \mathrm{kwaad}$. Al sou 
mens nie saam met Boers aanvaar dat hierdie polariteit fundamenteel is en Paulus se gedagtegang gegenereer het nie, is die blote raaksien van hierdie polariteit van belang in die konstruksie van Paulus se godsdienspatroon. Hierdie pole hoef nie op twee asse geplaas te word soos Boers gedoen het nie. Aan die een kant staan dan sonde/dood en hierteenoor goed doen/lewe. Paulus se konstruksie van beide pole is opvallend. Sonde en dood is nie sonder meer gejuk nie. Toe die mense God nie wou erken het nie, het God hulle oorgegee aan die sonde. Goddeloosheid lei daartoe dat God die mense oorgee aan onbetaamlikheid en perversiteit (Rom 1:24, 28). Ook dié teenpool bou Paulus tot 'n besondere konstruksie. Dit is nie goed doen wat na die lewe lei nie, maar lewe lei tot goed doen. Hierdie lewe is God se daad deur Christus. Lewe lei tot vrede by God (Rom 5:1) en dit lei weer tot lewe vir God (Rom 5).

Hierdie opvallende rol wat die Teo-logie in Paulus se godsdienspatroon speel, plaas 'n vraagteken agter Bultmann se siening dat Paulus deur sy Hellenistiese sendingveld verplig was om met die verkondiging van die Een God te begin.

Boers $(1984: 138 ; 142)$ se konstruksie van 'n dieptestruktuur wat polêr-genererend optree, het daartoe bygedra dat hy nie die sentrale rol van God en Christus se dinamiese optrede in Romeine 15: $8 \mathrm{v}$ raakgesien het nie.

Die dinamiese plek van God en Christus in die godsdienspatroon van Paulus en die dominante rol wat dié dinamiek speel, maak dit moeilik om te aanvaar dat hierdie beklemtoning uit 'n polemiese motief spruit. Hierdie dinamiek en die unieke verhouding lewe/goed doen by Paulus plaas ook vraagtekens agter opvattings dat Paulus stroom-af ten opsigte van die Judaïsme dink, soos wat WD Davies (1977: 4-39) beweer.

\subsection{Eleos in Romeine 15:9 as voorbeeld}

Die doel van hierdie studie is, soos reeds gesê, om die kontrolerende funksie van godsdienspatroon aan te toon vir die interpretasie van betekenis. Romeine 15:7-13 bied 'n goeie geleentheid om aan te toon dat verwysing nie altyd sinkronies-struktureel bo alle twyfel vasgestel kan word nie. In die geval van Romeine 15:7-13 hang dit saam met Paulus se opgewonde styl wat daartoe lei dat hy gedagtes aaneenryg en soms woorde wat herhaal moes gewees het, weglaat. Die leser moet hierdie weglatings aanvul. Die teks self mak meer aanvullings moont- 
lik. Die aaneenryging van gedagtes laat ook meer sintaktiese moontlikhede ontstaan. Die meer moontlikhede van afhanklikheid en van aanvulling open meer moontlikhede vir verwysing. Die moeilike vorm van Romeine 15:7-13 het in die negentiende eeu aanleiding gegee tot literêr-kritiese teorieë wat Romeine 15:8-12 as 'n na-Pauliniese invoeging beskou het of as 'n gedeelte wat verlê is uit hoofstuk 11 (Wilckens 1982: 104).

Romeine 15:7-13 maak egter eksegeties goeie sin en pas verder ook sonder teenspraak in Paulus se godsdienspatroon in. In 15:7 sê Paulus dat swakkes en sterkes, Jode en heidene wat in die gemeente is mekaar moet aanneem. In 15:8 begin hy duidelik maak waarom. Die sintaktiese aansluiting van $15: 9$ by $15: 8$ is nie sonder meer duidelik nie. ' $n$ Deel van hierdie onduidelikheid is of Christus se diens 'om die waarheid van God' in teenstelling (dè) met 'ter wille van God se ontferming' is of nie. Daar is nog 'n verdere moontlikheid. Die heidene loof God om sy ontferming wat werklikheid geword het in Christus se diens aan God se 'waarheid'. Christus se diens aan die Jode word dan die grond vir die heidene se lofprysing. Boers (1984: 142) verstaan 15:8 vv só en parafraseer: 'Christus het ' $n$ dienskneg van die besnydenis geword om die beloftes aan die vaders te bevestig, en so het hy dit moontlik gemaak vir die heidene om God te loof vir sy goedheid (ontferming).' Hierdie afhanklikheid druk Boers ook só uit: 'Dit is Christus se bevestiging van die beloftes aan die vaders wat op sy beurt die ontvangs van ontferming deur die heidene verseker het.' Omdat ons 'n nuwe subjek in 15:9 het, lyk hierdie moontlikheid nie baie aantreklik nie. Die meeste eksegete (Wilckens 1982: 106) en ook die nuwe Afrikaanse vertaling sien Christus se koms as die bevestiging van God se beloftes aan die vadere èn as grond vir die lofprysing van die heidene. 'n Belangrike beswaar teen hierdie siening is deur Wilckens (1982: 106) na vore gebring. Hierdeur word die besondere korrespondensie tussen Jode en heidene asook tussen die 'ter wille van die waarheid' en die 'ter wille van die ontferming' opgehef. As 15:9 dus van Christus se koms afhanklik gemaak word, het Christus se koms na Israel geen voorrang bo sy koms na die heidene nie. Christus se koms het dan van die staanspoor af universele betekenis. Indien 15:9 van légō afhanklik gemaak word, word die 'heilshistoriese volgorde' (Wilckens 1982: 106) beklemtoon: eers vir Israel, dan ook vir die heidene. Sintakties is daar iets vir albei laasgenoemde moontlikhede te sê, soos die geskiedenis van 15:7-13 se uitleg dan ook aantoon.

Word die godsdienspatroon van Paulus egter ook in die spel gebring, 
is 'n keuse nie meer moeilik nie. In die godsdienspatroon van Paulus is God 'n dinamiese God en nie eintlik die universele God nie. Hierdie dinamiek van God se soewereiniteit word duidelik in sy betroubaarheid. As Christus kom, word dit duidelik dat God die God van die verbond is. Hy het Israel gekies en bly getrou aan sy beloftes. Die dinamiek van God se soewereiniteit word ook duidelik in sy ontferming. Die heidene wat beelde vereer het, is deur God se soewereine mag oorgegee aan 'n skrikwekkende bestaan. Nou het God besluit om ook aan hulle die verlossing te bied - dit het Hy gedoen omdat $\mathrm{Hy}$ die soewereine ontfermende God is. God is nie sonder meer die universele God nie - sy universaliteit is gekwalifiseerd. In Paulus se godsdienspatroon speel die motief 'eers aan Israel dan ook vir die heidene' 'n duidelike rol. Paulus handhaaf 'n opvatting wat ook in sy dag meermale voorkom. Toe Israel Christus verwerp het, het God die koninkryk van hulle weggeneem en aan gelowiges uit die Jode en heidene gegee (vgl Engelbrecht 1985: 124-128; vgl 1 Tess 2:14-16).

Hierdie element in Paulus se godsdienspatroon het ook in die dieptestruktuur van Romeine 'n rol gespeel (11:17-32; 1:16; Boers 1982: 4).

Teen die agtergrond van die Romeinebrief se makrostruktuur verwys eleos na 'n daad van God wat volg op Christus se diens aan Israel, sodat God wat sy beloftes aan die vadere gegee het, se betroubaarheid bevestig kon word.

Indien Paulus se godsdienspatroon ook in die spel gebring word, word hierdie aspek van eleos se verwysing bevestig. 'Ontferming' verwys dan in 15:9 na God se soewereine daad toe God Hom ook oor die heidene ontferm het en Christus ook hulle tot sy gemeente aangeneem het. Natuurlik was hierdie nuwe daad van God verrassend en onverwags. Maar omdat Hy die soewereine God is wat dooies lewend maak en dinge wat nie bestaan nie, tot stand bring deur sy woord (4:17) is dit nie verrassend nie. Hy is immers ook dié God wat deur die diens van Christus sy beloftes aan die vadere bevestig het, omdat hy die betroubare God is.

In 15:7-13 is Teo-logie, Christologie en ekklesiologie vervleg. Dit is tipies van Paulus se godsdienspatroon. Die gedeelte het verder 'n etiese toespitsing. Die swakkes en sterkes moet mekaar aanvaar. Jode en heidene in die gemeente moet God eendragtig prys vir sy soewereine betroubaarheid en ontferming. Die verskeidenheid van God se optrede word deur God opgehef in Christus, wat sy gemeente uit Jode en heidene aangeneem het. Uit die verskeidenheid van God se soewereine dinamiek word die gemeente uit Jode en heidene deur Christus 
aangeneem. Hierdie gemeente moet God se soewereiniteit eendragtig prys. Ook hierdie etiese toespitsing is tipies van Paulus se godsdienspatroon. Dit is dus onnodig om in Romeine 15:7-13 onoplosbare sintaktiese spanninge te sien en nog onnodiger om hierdie spanninge deur teorieë van literêr-kritiese post-Pauliniese toevoegings òf verlegging binne die Romeinebrief te verklaar.

Teen die agtergrond van Paulus se godsdienspatroon is Dabelstein (1981: 107) se siening dat dit in Romeine 15:7-13 om ' $n$ universele heilsbelofte aan die mensheid gaan, onwaarskynlik. 'n Universele heilsbelofte aan die mensheid figureer nie in Paulus se godsdienspatroon nie. In dié gedeelte het ons 'n gekwalifiseerde universalisme wat begrens word deur 'deur die geloof', die eenheid van die kerk en 'n volgorde van eers aan die Jode en dan ook aan die heidene. Hierdie motiewe tree duidelik na vore in Paulus se godsdienspatroon.

Hierdie studie het getoon dat indien die godsdienspatroon van ' $n$ skrywer verantwoordelik vasgestel èn benut word, dit 'n bydrae tot verwysing lewer. Verantwoordelik vasgestel, beteken dat die godsdienspatroon veral sinkronies vasgestel sal word. Verantwoordelik benut, beteken dat die godsdienspatroon in samehang met die vasstelling van verwysing in die mikro-omgewing met inagneming van die dieptestruktuur aangewend sal word. Die rol wat die godsdienspatroon speel, moet veral kontrolerend wees as derde fase van interpretasie.

Semantiese verhoudings, dit wil sê resiproke verhoudings tussen woorde in 15:9 asook struktureel-sintaktiese verhoudings in die mikroteks kon nie 'n finale bydrae lewer om die betekenis in 15:9 te interpreteer nie. Die semantiese dieptestruktuur van die Romeinebrief en die godsdienspatroon as semantiese dieptestruktuur van Paulus se denke, het hier 'n finale bydrae gelewer. Verantwoordelik vasgestel en benut, kan die godsdienspatroon ' $n$ bydrae tot die interpretasie van betekenis lewer, al is dit dan hoogstens kontrolerend. 
BYLAE: DIE ONSTAAN VAN 'N PAULUSTEKS

\begin{tabular}{|c|c|}
\hline PRIMÊRE IMPULS & SEKONDÊRE IMPULS \\
\hline GODSDIENSPATROON: & $\begin{array}{l}\text { OMSTANDIGHEDE VAN PAULUS OF VAN } \\
\text { DIE GEMEENTE: opgewing; ander } \\
\text { godsdienste; ander 'evangelie' }\end{array}$ \\
\hline \multirow{2}{*}{$\begin{array}{l}\text { I GRONDSTRUKTUUR: } \\
\text { God is die lewende God; } \\
\text { God moet as die lewende } \\
\text { God erken word. } \\
\text { II EERSTEVLAKMOTIEWE OP DIE } \\
\text { OPPERVLAKTE: } \\
\text { antitese: God/afgode; } \\
\text { lewe/dood. Motiewe } \\
\text { rondom Christus en die } \\
\text { Heilige Gees. }\end{array}$} & $\begin{array}{c}\downarrow \\
\text { OOGMERK MET 'N BRIEF }\end{array}$ \\
\hline & \\
\hline \multirow[b]{3}{*}{ W } & $\begin{array}{l}\text { Semantiese diepte- } \\
\text { struktuur van die } \\
\text { brief as teks }\end{array}$ \\
\hline & $\begin{array}{l}\text { OPPERVLAKTESTRUKTUUR } \\
\text { semantiese } \\
\text { resiprositeit }\end{array} \longrightarrow \downarrow_{\text {sintaks }}$ \\
\hline & $\sqrt{1}$ \\
\hline \multicolumn{2}{|c|}{ TEMAS } \\
\hline & TEKS \\
\hline
\end{tabular}

\section{Literatuurverwysings}

BRANDENBURGER, E 1962. Adam und Christus.Neukirchen: Neukirchener Verlag.

BRANDENBURGER, E 1985. Paulinische Schriftauslegung in der Kotroverse um das Verheissungswort Gottes (Rom 9). ZThK 82/1, 1-47.

BOERS, $H$ 1982. The problem of Jews and Gentiles in the macro-structure of Romans. Neotestamentica 15, 1-11.

BOERS, $\mathrm{H}$ 1984. The meaning of Christ in Paul's writings: A structuralist-semiotic study. BTB 14/4, 131-44.

BORNKAMM, G 1970. Paulus. Stuttgart: Kohlhammer.

BULTMANN, R 1958. Theologie des Neuen Testaments. Tübingen: Mohr.

BULTMANN, R 1979. Die Geschichte der synoptischen Tradition. Göttingen: Vandenhoeck.

DAHL, NA 1977. Studies in Paul's theology for the early Christian mission. Minneapolis: Augsburg.

DAVIES, WD 1977. Paul and the people of Israel. NTS 24, 4-39.

DE VILLIERS, PGR 1984. The interpretation of a text in the light of its socio-cultural setting. Neotestamentica $18,66-79$. 
ELLINGWORTH, P \& NIDA, EA 1976. A translator's handbook on Paul's letters to the Thessalonians. [New York]: United Bible Societies.

ENGELBRECHT, E 1985. Geregtigheid en sending in die Matteusevangelie. Ongepubliseerde DD-proefskrif, Universiteit van Pretoria.

GÜTTGEMANNS, E 1971. 'Gottesgerechtigkeit' und Strukturale Semantik, in Studia linguistica neotestamentica. München: Kaiser.

KAHL, B 1977. Traditionsbruch und Kirchengemeinschaft bei Paulus. Stuttgart: Calwer.

KÄSEMANN, E 1972. Paulinische Perspektiven. Tübingen: Mohr.

KÄSEMANN, E 1980. An die Römer. Tübingen: Mohr.

KIM, S 1981. The origin of Paul's gospel. Tübingen: Mohr.

LÜDEMANN, G 1983. Paulus und das Judentum. München: Kaiser.

PATTE, D 1983. Paul's faith and the power of the gospel. Philadelphia: Fortress.

PELSER, GMM 1982. Doxa in die Romeinebrief, in Die kerk in die wêreld: ' $n$ Bundel opstelle aangebied aan prof dr AD Pont by sy 25-jarige ampsjubileum. Pretoria: HAUM.

SANDERS, EP 1977. Paul and Palestinian Judaism. London: SCM.

SCHNEIDER, J 1932. Doksa. Eine bedeutungsgeschichtliche Studie. Gütersloh: Bertelsmann.

VON RAD, G 1960. s v dóxa ThWNT.

WILCKENS, U 1978. Der Brief an die Römer (Röm 1-5). Zürich: Benziger Verlag.

WILCKENS, U 1982. Der Brief an die Römer (Röm 12-16). Zurich: Benziger Verlag. 